\title{
POTENSI PEMANFAATAN LIMBAH PEMBAKARAN BATUBARA (BOTTOM ASH) PADA PLTU SEBAGAI MEDIA TANAM DALAM UPAYA MENGURANGI PENCEMARAN LINGKUNGAN
}

\author{
Rr. Mekar Ageng Kinasti ${ }^{1}$; Endah Lestari ${ }^{2}$; Devita Mayasari ${ }^{3}$ \\ Sekolah Tinggi Teknik PLN \\ mekar.ageng@sttpln.ac.id ${ }^{1}$, endahlestari@sttpln.ac.id ${ }^{2}$, devita@sttpln.ac.id ${ }^{3}$
}

\begin{abstract}
The impact of environmental pollution is now beginning to perceive by all levels of humans and in the world such as global warming, until climate change has inspired the research on the utilization of waste coal combustion (Bottom Ash) power plant. This research uses Bottom Ash (BA) from PLTU (Electric Steam Power Plant) Suralaya, by choosing Selada (Lactuca sativa), Sawi (Ipomea Autica), and Kangkung (Brassica rapa var). Percentage BA used as planting media is $0 \%, 25 \%, 50 \%, 75 \%$, and $100 \%$. BA serves to accelerate the process of rupture and plant growth due to the availability of $\mathrm{Ca}, \mathrm{Mg}, \mathrm{Na}, \mathrm{K}, \mathrm{N}, \mathrm{P}, \mathrm{S}$ and Fe elements. Planting media for Lettuce plant species is $25 \%$. The corresponding percentage of BA as planting media for Plant Sawi species is $25 \%$, and $50 \%$. While in the Kangkung plant BA percentage that is suitable for use as a planting media is 25\%, 50\%, and 75\%. The apparent anomaly at this test are Kangkung percentage $75 \%$ and Lettuce $50 \%, 75 \%$ stems become longer, and leaves become slightly even in 100\% Bottom Ash percentage, Lettuce grows with smaller size/dwarf. The amount of nutrient excess need to be accurately measured through laboratory test first. With further testing it is hoped that the utilization of coal ash waste (Bottom Ash) becomes more real and effective as a growing media seen from risk and danger aspects.
\end{abstract}

Keywords: Bottom Ash, Planting Media, Vegetable Crops, Environmental Pollution, Hydroponic

\begin{abstract}
Abstrak
Pencemaran lingkungan yang sekarang ini dampaknya mulai dirasakan diseluruh belahan dunia seperti isu pemanasan global, sampai dengan perubahan iklim yang terjadi telah menginspirasi penelitian pemanfaatan Bottom Ash PLTU. Penelitian kali ini menggunakan Bottom Ash (BA) dari PLTU Suralaya, dengan memilih tanaman Selada (Lactuca sativa), Sawi (Ipomea Autica), dan Kangkung (Brassica rapa var). Prosentase BA yang dipergunakan sebagai media tanam adalah 0\%, 25\%, 50\%, 75\%, dan 100\%. BA berfungsi mempercepat proses pecah benih dan pertumbuhan tanaman karena ketersediaan unsur $\mathrm{Ca}, \mathrm{Mg}, \mathrm{Na}, K, \mathrm{~N}, \mathrm{P}, \mathrm{S}$ dan Fe. Prosentase BA yang sesuai untuk tanaman Selada adalah 25\%. Prosentase BA yang sesuai untuk tanaman Sawi adalah 25\%, dan 50\%, sedangkan pada tanaman Kangkung prosentase BA yang sesuai adalah 25\%, $50 \%$, dan 75\%. Gejala kelebihan unsur hara juga dijumpai pada hasil tanamannya. Anomali yang tampak adalah Kangkung prosentase 75\% dan Selada 50\%, 75\% batang menjadi lebih panjang, daun menjadi sedikit, bahkan pada prosentase Bottom Ash 100\% Selada tumbuh dengan ukuran yang lebih kecil (kerdil). Jumlah kelebihan unsur hara perlu di ukur dengan akurat melalui uji laboratorium terlebih dahulu. Dengan demikian pemanfaatan limbah abu batubara (Bottom Ash) menjadi lebih nyata dan tepat guna sebagai media tanam dilihat dari aspek resiko dan bahayanya.
\end{abstract}

Kata Kunci: Bottom Ash, Media Tanam, Tanaman Sayuran, Pencemaran Lingkungan, Hidroponik

\section{PENDAHULUAN}

Pencemaran lingkungan yang belakangan ini berdampak terhadap daya dukung lingkungan, seperti pada isu lingkungan global terkini terkait dengan adanya hujam asam sampai dengan perubahan iklim yang terjadi. Penelitian ini merupakan lanjutan penelitian sebelumnya sesuai dengan road map yang telah di tentukan. Penelitian ini dilakukan sebagai bentuk keseriusan dalam mengupayakan kelestarian lingkungan. Hal tersebut lebih dikarenakan meskipun penelitian mengenai pemanfaatan Bottom Ash dan Fly Ash sudah sangat banyak, akan tetapi sampai saat ini pemanfaatan limbah abu sisa pembakaran batubara ini belum dirasakan secara masif dan merata, dengan pemanfaatan dan pengelolaan yang baik diharapkan dapat mencegah atau mengatasi masalah lingkungan yang serius dalam upaya pelestarian lingkungan hidup.

Penelitian ini difokuskan pada pemanfaatan abu dasar (Bottom Ash) sebagai limbah PLTU berbahan bakar batubara sebagai media tanam dengan metode hidroponik pada tanaman Kangkung, Selada, dan Sawi dengan persentase $B A$ yang masih sama seperti penelitian sebelumnya, yaitu 0\%, 25\%, 50\%, 75\%, dan 100\%. Kendala yang mungkin akan muncul pada saat penelitian berlangsung juga akan di bahas dalam penelitian kali ini sehingga hasil penelitian tahap kedua ini dapat dijadikan perbandingan dalam melakukan kajian lebih lanjut.

Berdasarkan hal-hal yang melatarbelakangi dan rumusan masalah usulan penelitian ini, tujuan yang dapat dicapai adalah: 
a. Mewujudkan sikap sadar lingkungan pada setiap elemen yang terlibat di dalamnya sehingga terwujudnya wawasan lingkungan melalui pemanfaatan sisa pembakaran batubara (BA)

b. Terciptanya pembangunan berkelanjutan yang berwawasan lingkungan melalui metode hidroponik yang cocok diterapkan pada lahan sempit dan pasokan air terbatas.

c. Mengetahui pengaruh masing-masing persentase bottom ash terhadap masingmasing jenis tanaman.

d. Mengetahui persentase penambahan bottom ash sebagai media tanam yang cocok dengan pertumbuhan jenis tanaman yang dipilih.

\section{A. Limbah Kegiatan PLTU}

Sistem pembakaran batubara PLTU pada umumnya adalah Fluidized bed system yaitu sistem saat udara ditiup dari bawah menggunakan blower sehingga benda padat di atasnya berkelakuan mirip fluida. Teknik fluidisasi dalam pembakaran batubara adalah teknik yang paling efisien dalam menghasilkan energi. Setelah temperatur pasir mencapai temperatur bakar batubara $\left(300^{\circ} \mathrm{C}\right)$ maka diumpankanlah batubara. Sistem ini menghasilkan abu terbang dan abu yang turun di bawah alat. Abuabu tersebut disebut dengan Fly ash dan Bottom Ash. Abu batubara diklasifikasikan dalam beberapa kelompok tergantung pada komposisi elemen makronya. Umumnya pengklaisifikasian tersebut adalah:

1. Abu batubara kelas $F$ dengan kadar Fe tinggi

2. Abu batubara kelas $F$ dengan kadar Fe rendah

3. Abu batubara kelas $\mathrm{C}$ dengan kadar $\mathrm{CaO}$ tinggi

4. Abu batubara kelas menengah

Abu terbang (fly ash) didefinisikan sebagai butiran halus hasil residu pembakaran batubara atau bubuk batubara. Abu terbang hasil pembakaran merupakan hasil penguraian mineral silikat, sulfat, sulfida, karbonat, dan oksida yang terdapat dalam batubara (ASTM C.618). Pembakaran batubara di pembangkit listrik berlangsung pada suhu antara $1.100-1.500{ }^{\circ} \mathrm{C}$, atau pada suhu oksidasi dan reduksi. Pada kondisi ini akan terjadi perubahan secara kimia dan fisika, sehingga komposisi abu sisa pembakaran akan jauh berbeda dengan komposisi mineral aslinya. Abu tersebut merupakan campuran partikel dengan komposisi yang sangat kompleks (Prijatama, dkk., 1994 dalam Kurniawan, dkk.,2010).

Tabel 1. Sifat fisik khas Bottom Ash

\begin{tabular}{|l|l|l|}
\hline \multicolumn{1}{|c|}{$\begin{array}{c}\text { Sifat Fisik Bottom } \\
\text { Ash }\end{array}$} & Basah & Kering \\
\hline Bentuk & Angular/bersiku & Berbutir kecil/granular \\
Warna & Hitam & Abu-abu gelap \\
Tampilan & Keras, mengkilap & Seperti pasir halus, sangat \\
& & berpori \\
Ukuran (\% lolos & No. $4(90-100 \%)$ & 1,5 s.d. $3 / 4(100 \%)$ \\
ayakan) & No. $10(40-60 \%)$ & No. $4(50-90 \%)$ \\
& No. $40(\leq 10 \%)$ & No. $10(10-60 \%)$ \\
& No. $200(\leq 5 \%)$ & No.40 $(0-10 \%)$ \\
Berat jenis spesifik & $2,3-2,9$ & $2,1-2,7$ \\
Berat unit kering & $060-1440 \mathrm{~kg} / \mathrm{m}^{3}$ & $720-1600 \mathrm{~kg} / \mathrm{m}^{3}$ \\
Penyerapan & $0,3-1,1 \%$ & $0,8-2,0 \%$ \\
\hline
\end{tabular}

Abu dasar atau lebih dikenal dengan Bottom Ash adalah sisa proses pembakaran batubara pada pembangkit tenaga listrik yang memunyai ukuran partikel lebih besar dan lebih berat dari pada fly ash, sehingga Bottom Ash akan jatuh pada dasar tungku pembakaran (boiler). Bottom Ash dikategorikan menjadi dry Bottom Ash dan wet Bottom Ash/boiler slag berdasarkan jenis tungkunya. Dry bottom boiler yang menghasilkan dry Bottom Ash dan slag-tap boiler serta cyclone boiler yang menghasilkan wet Bottom Ash (boiler slag). Sifat dari Bottom Ash sangat bervariasi karena dipengaruhi oleh jenis batubara dan sistem pembakarannya. Komposisi kimia dari Bottom Ash sebagian besar tersusun dari unsur-unsur $\mathrm{Si}, \mathrm{Al}, \mathrm{Fe}$, $\mathrm{Ca}$, serta $\mathrm{Mg}, \mathrm{S}, \mathrm{Na}$, dan unsur kimia lain. Kandungan silikat dan alumina yang terkandung dalam Bottom Ash ini bersifat aktif karena dapat bereaksi dengan komponen lain. Silika dalam Bottom Ash berperan membantu pelarutan unsur $P$ dalam media tanam yang mengandung unsur hara phospat.

\section{B. Karakteristik Sekam Padi Bakar}

Media tanam lain yang akan digunakan sebagai media tanam adalah sekam padi bakar. Tidak berbeda dengan Bottom Ash, salah satu komponen dalam sekam padi bakar adalah Silika nabati (Dahliana dkk, 2013). Arang sekam atau sekam bakar banyak dimanfaatkan sebagai campuran media tanam dan media tanam murni (tanpa campuran). Arang sekam digunakan sebagai media tanam hidroponik dan campuran media tanam berbasis tanah. Arang sekam merupakan media tanam yang baik karena memiliki kandungan SiO2 52\% dan unsur C 31\% serta komposisi lainnya seperti $\mathrm{Fe} 203, \mathrm{~K} 2 \mathrm{O}, \mathrm{MgO}, \mathrm{CaO}, \mathrm{MnO}$ dan $\mathrm{Cu}$ dalam jumlah yang sangat sedikit. Unsur hara pada arang sekam antara lain nitrogen $(\mathrm{N}) 0.32 \%$, phosphat (P) $0.15 \%$, kalium (K) $0.31 \%$, calsium (Ca) 0.96\%, Fe 180 ppm, Mn 80.4 ppm, Zn 14.10 ppm dan $\mathrm{pH} 8,5$ - 9,0. Berikut merupakan komposisi kimia dari sekam padi bakar (arang sekam). Silika bukanlah unsur hara tetapi merupakan unsur penunjang yang penting bagi pertumbuhan tanaman, karena silika mengoptimalkan pelarutan dan penyerapan unsur phospat. Silika membuat tanaman menjadi kuat atau kokoh/ tegak dan tidak mudah layu, proteksi hama penyakit, meningkatkan oksidasi akar tanaman sehingga akar tanaman lebih panjang, kuat dan serabut lebih banyak. Si berperan dalam meningkatkan fotosintesis dan resistensi tanaman terhadap cekaman biotik (serangan hama dan penyakit) dan abiotik (kekeringan, salinitas, alkalinitas, dan cuaca ekstrim) (Balai Penelitian Tanah, 2010).

\section{Hidroponik}

Istilah hidroponik berasal dari bahasa Latin yang berarti hydro (air) dan ponos (kerja). Selanjutya hidroponik didefinisikan secara ilmiah sebagai suatu cara budidaya tanaman tanpa menggunakan tanah, akan tetapi menggunakan media inert seperti gravel, pasir, peat, vermikulit, pumice atau sawdust, yang diberikan larutan hara yang mengandung semua elemen essensial yang 
diperlukan untuk pertumbuhan dan perkembangan normal tanaman (Resh, 1998). Kebutuhan air pada hidroponik lebih sedikit daripada kebutuhan air pada budidaya dengan tanah. Penggunaan air pada metode hidroponik menjadi lebih efisien, jadi cocok diterapkan pada daerah yang memiliki pasokan air yang terbatas. Sistem hidroponik yang di pergunakan dalam penelitian ini adalah hidroponik sistem wick (sumbu).

\section{METODOLOGI PENELITIAN}

Penelitian ini dimaksudkan untuk mengembangkan potensi pemanfaatan limbah pembakaran batubara berupa Bottom Ash pada PLTU sebagai media tanam menggunakan teknik hidroponik sistem Wick. Prosentase Botom Ash yang dipergunakan adalah sebanyak 100\%, 75\%, $50 \%$, 25\%, dan 0\%. Kelima prosentase tersebut di ujikan pada ketiga jenis tanaman sayuran, masing masing prosentase pada tiap jenis tanaman diulang sebanyak 3 kali pengujian.

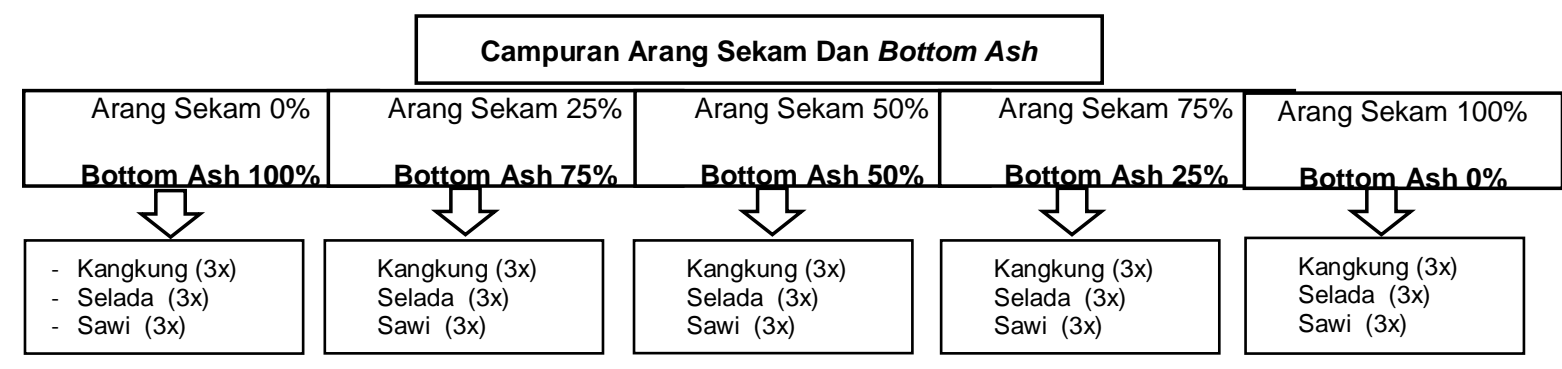

Gambar 1. Variasi prosentase Penggunaan Bottom ASh

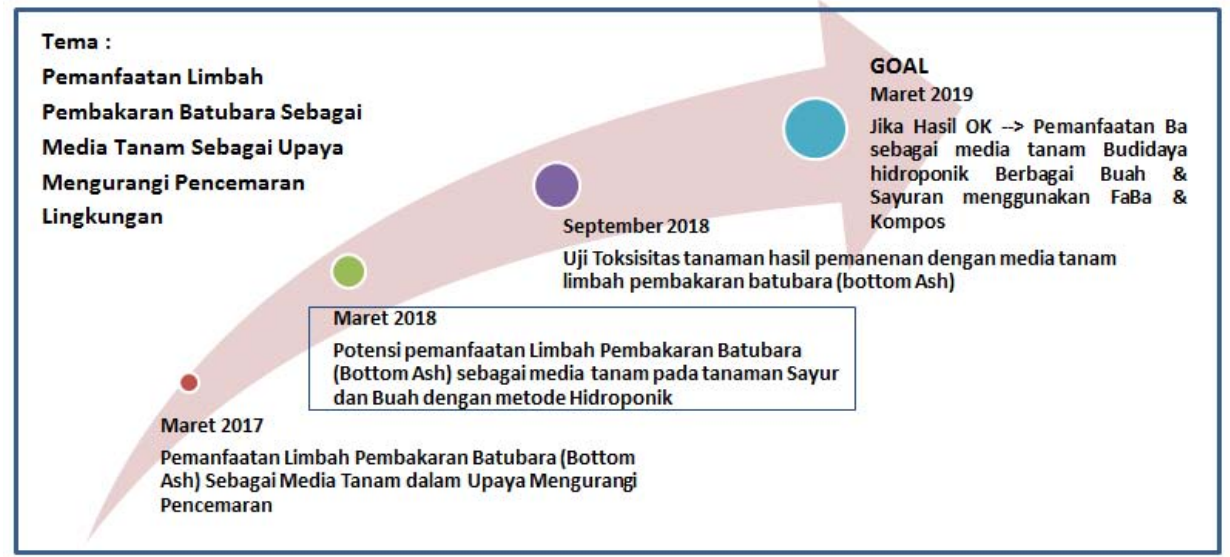

Gambar 2. Road Map Penelitian dari Tahun 2017 s/d 2019

\section{A. Persiapan Alat dan Bahan}

Persiapan yang dilakukan dalam penelitian ini selain studi literatur adalah pembelian alat dan bahan. Peralatan yang dipergunakan dalam penelitian ini antara lain seperti Paranet 50\%, Bak Hydroponik Jumbo, Sumbu Kompor, Fiber Warna / Impraboard, Gelas Pot Hydroponik, Spray Nutrisi, Sarung Tangan, Gunting Tanaman, Masker Wajah Anti Debu, Bambu, Paku, Rafia, Kertas HVS A4 80 gram, ATK (Ballpoint, Pensil, ClipBoard, Mistar \& Cutter, Plester Kertas, Spidol Permanent). Bahan bahan yang dipergunakan dalam penelitian lanjutan kali ini adalah Bottom Ash PLTU Suralaya ukuran medium, Benih Tanaman Hidroponik Selada Grand Rapids, Benih Tanaman Hidroponik Kangkung Walet, Benih Tanaman Hidroponik Caisim Tosakan, Sekam Arang, Penutrisi AB MIX Trubus dan Air.

\section{B. Pengujian Kondisi Bahan}

Langkah pertama yang dilakukan adalah pengujian bahan - bahan yang dipergunakan. Bahan yang akan digunakan untuk penelitian haruslah dalam kondisi yang baik atau siap pakai. Kualitas yang di tetapkan adalah kualitas terbaik. Bottom Ash yang dipergunakan adalah Bottom Ash PLTU Suralaya dengan kondisi kering, berukuran medium dan relatif bersih. Air yang dipergunakan sebagai pencampur nutrisi tanaman pada penelitian ini adalah air kualitas PALYJA Duri Kosambi Cengkareng Jakarta Barat. Persyaratan air bersih telah dimiliki oleh air yang digunakan dalam penelitian kali ini, yaitu sesuai SNI (SK-SNI-S-041989-F) tidak berwarna, tidak berasa, dan tidak berbau, serta dapat diminum apabila sudah dimasak. Benih tanaman yang dipergunakan dalam kondisi bersih dan siap pakai (dalam wadah terbungkus rapat). Sekam yang dipergunakan sebagai media pelengkap dalam penelitian kali ini 
adalah tetap sama seperti penelitian sebelumnya yaitu Sekam Bakar produksi PT. Trubus Mitra Swadaya dengan kualitas terbaik. Kondisi sekam bakar saat dipergunakan adalah berwarna hitam, dalam keadaan kering dan siap untuk dipakai.

\section{Penimbangan Variasi Bottom Ash}

Prosentase Bottom Ash yang digunakan mulai dari $0 \%, 25 \%, 50 \%, 75 \%$, sampai $100 \%$. Pot yang dipergunakan adalah pot plastik seperti gelas dengan diameter $7 \mathrm{~cm}$ dan tinggi $12,5 \mathrm{~cm}$. Masing masing pot diisi oleh Bottom Ash sesuai dengan prosentasenya (Gambar 3), kemudian dalam setiap variasi prosentase akan di ulang sebanyak tiga kali. Variasi campuran media tanam dapat dilihat pada tabel di bawah ini (Tabel 2)

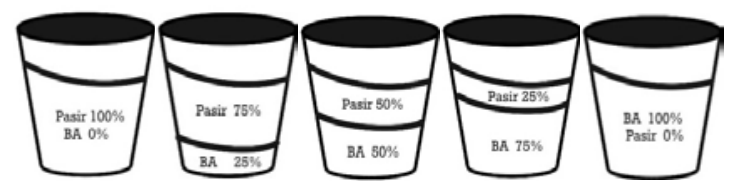

Gambar 3. Variasi prosentase penggunaan Bottom Ash sebagai media tanam

Tabel 2. Variasi peritungan berat isi kandungan Bottom Ash pada pot.

\begin{tabular}{|c|l|c|c|c|c|c|}
\hline \multirow{2}{*}{ No } & \multicolumn{1}{|c|}{ Tanaman } & \multicolumn{4}{|c|}{ Perhitungan Kandungan Bottom Ash } \\
\cline { 3 - 7 } & & $\mathbf{0 \%}$ & $\mathbf{2 5 \%}$ & $\mathbf{5 0 \%}$ & $\mathbf{7 5 \%}$ & $\mathbf{1 0 0 \%}$ \\
\hline 1 & Selada (Lactuca sativa) & $0 \mathrm{gr}$ & $50 \mathrm{gr}$ & $100 \mathrm{gr}$ & $150 \mathrm{gr}$ & $200 \mathrm{gr}$ \\
\hline 2 & Sawi (Ipomea auatica) & $0 \mathrm{gr}$ & $50 \mathrm{gr}$ & $100 \mathrm{gr}$ & $150 \mathrm{gr}$ & $200 \mathrm{gr}$ \\
\hline 3 & $\begin{array}{l}\text { Kangkung (Brassica rapa } \\
\text { var) }\end{array}$ & $0 \mathrm{gr}$ & $50 \mathrm{gr}$ & $100 \mathrm{gr}$ & $150 \mathrm{gr}$ & $200 \mathrm{gr}$ \\
\hline
\end{tabular}

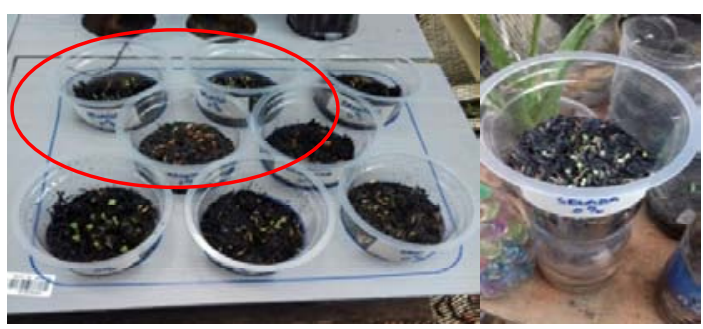

Gambar 4. Variasi prosetase $0 \%$ Bottom Ash pada tanaman Selada (Lactuca sativa).

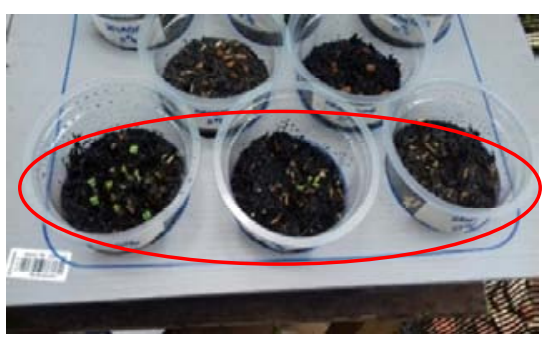

Gambar 5. Variasi prosetase $0 \%$ Bottom Ash pada tanaman Sawi (Ipomea auatica).

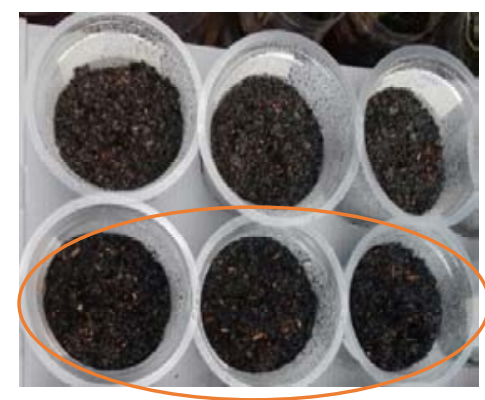

Gambar 6. Variasi prosetase 25\% Bottom Ash pada tanaman Selada (Lactuca sativa).

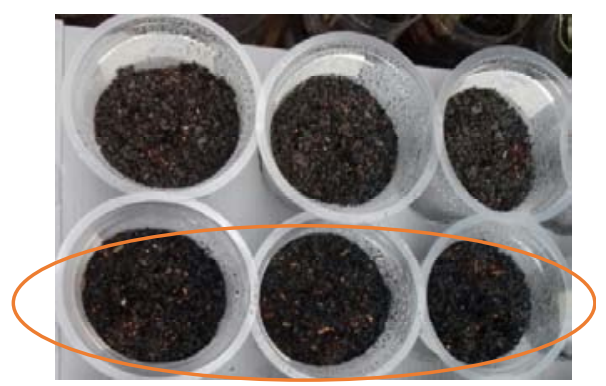

Gambar 7. Variasi prosetase $25 \%$ Bottom Ash pada tanaman Sawi (Ipomea auatica).

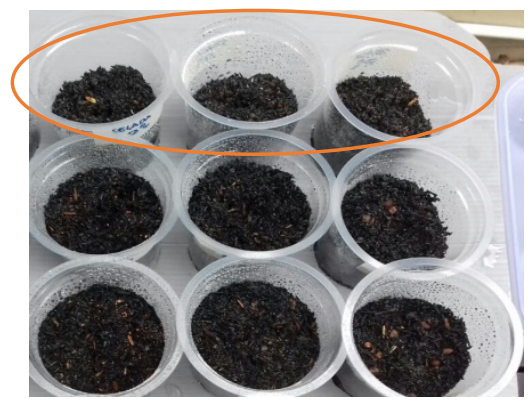

Gambar 8. Variasi prosetase $50 \%$ Bottom Ash pada tanaman Selada (Lactuca sativa).

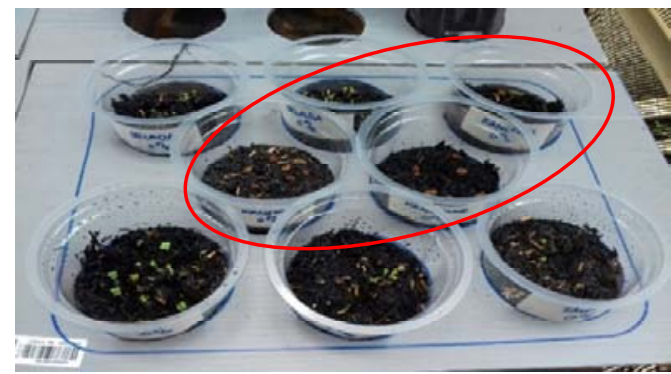

Gambar 9. Variasi prosetase 0\% Bottom Ash pada tanaman Kangkung (Brassica rapa var).

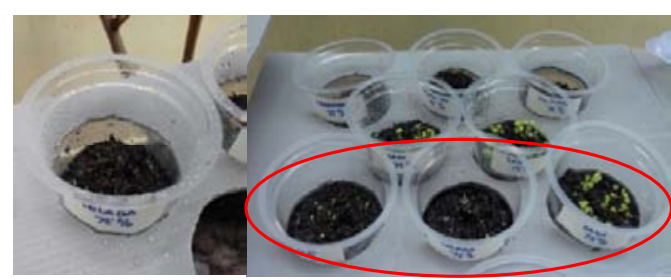

Gambar 10. Variasi prosetase $75 \%$ Bottom Ash pada tanaman Selada (Lactuca sativa). 


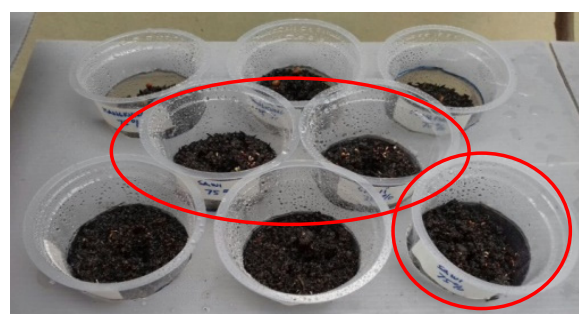

Gambar 11. Variasi prosetase 75\% Bottom Ash pada tanaman tanaman Sawi (Ipomea auatica).

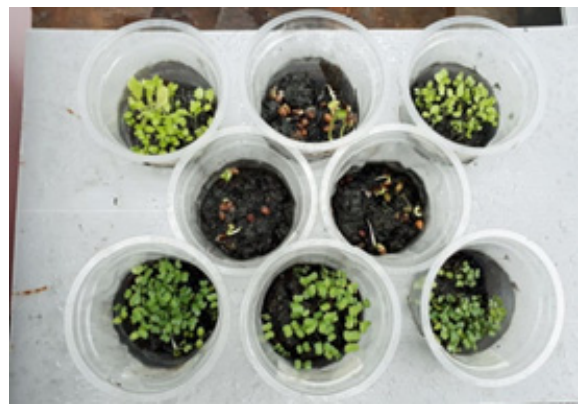

Gambar 12. Variasi prosetase $75 \%$ Bottom Ash pada tanaman Kangkung (Brassica rapa var).

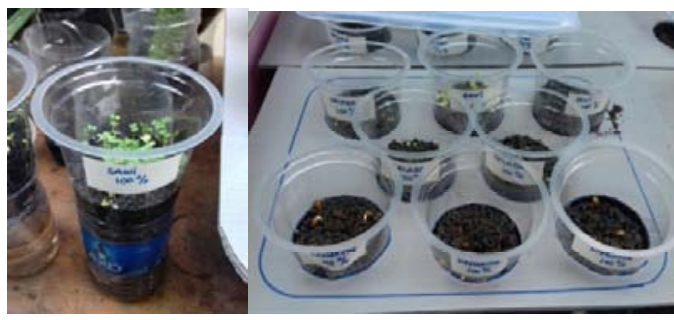

Gambar 13. Variasi prosetase 100\% Bottom Ash pada tanaman Selada (Lactuca sativa), Sawi (Ipomea auatica), Kangkung (Brassica rapa var).

\section{Pembahasan}

\section{A. Pengujian Pertama Seluruh Prosentase}

Pengujian pertama dilakukan pada tanaman (Lactuca sativa), Sawi (Ipomea auatica), Kangkung (Brassica rapa var). Dimulai dari prosentase $0 \%$ Bottom Ash, 25\% Bottom Ash, 50\% Bottom Ash, $75 \%$ Bottom Ash sampai dengan 100\% Bottom Ash. Grafik pertama (Grafik 1) menunjukkan bahwa tanaman selada memiliki waktu pecah benih tercepat dan stabil yaitu 2 hari semenjak masa tanam. Tanaman Sawi memiliki waktu pecah benih 3 hari pada prosentase $0 \%, 25 \%$, dan $50 \%$, satu hari lebih lama jika dibandingan dengan Selada. Sedangkan pada prosentase Bottom Ash 75\% dan $100 \%$. Benih Sawi pecah pada hari ke 2 hari. Tanaman Kangkung dengan prosentase Bottom Ash sebesar $0 \%$, dan $25 \%$ mengalami pecah benih pada hari ke 5 semenjak masa tanam, sedangkan dengan penambahan Bottom Ash sebesar 50\%, $75 \%$, dan $100 \%$, Kangkung mengalami pecah benih pada hari ke 4 atau satu hari lebih cepat dibandingkan dengan prosentase 0, 25 dan 50 .

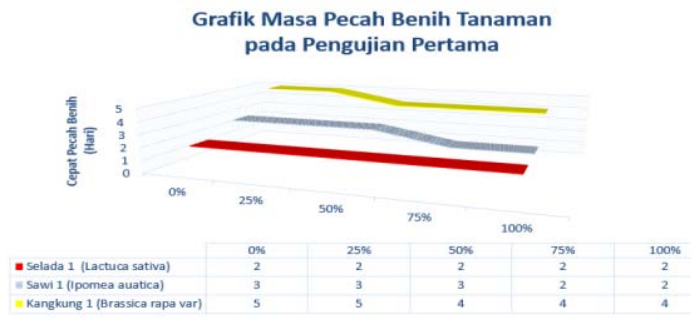

Grafik 1. Grafik Masa Pecah Benih Tanaman pada Pengujian Pertama

\section{B. Pengujian Kedua Seluruh Prosentase}

Pengujian kedua dilakukan pada tanaman yang sama yaitu (Lactuca sativa), Sawi (Ipomea auatica), Kangkung (Brassica rapa var). Tanaman selada yang di tanam pada media biasa (sekam padi bakar) dengan tambahan 0\% BA mengalami pecah benih pada hari ke 3 , sedangkan dengan penambahan prosentase BA sebanyak 25\%, 50\%, $75 \%$, dan $100 \%$, tanaman Selada mengalami pecah benih dengan waktu yang lebih cepat, yaitu 2 hari.

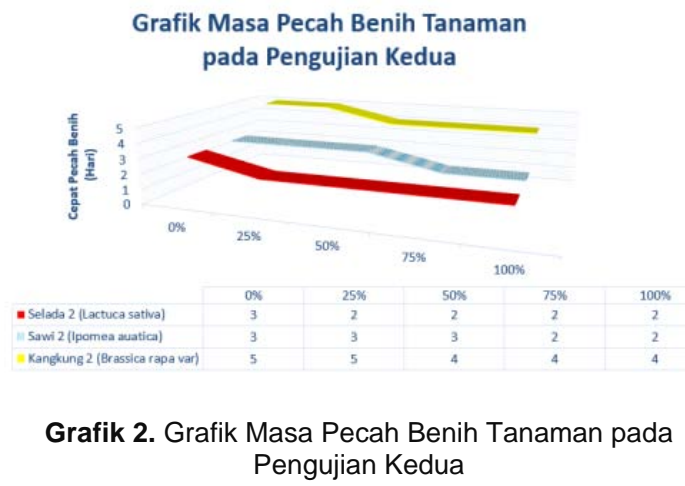

Tanaman sawi menunjukkan respon yang relatif sama seperti pengujian tahap pertama, yaitu cenderung mengalami pecah benih yang semakin cepat dengan prosentase BA yang semakin banyak. Pada prosentase 0\% BA, Sawi mengalami pecah benih pada hari ke 3 , demikian halnya pada Sawi dengan kandungan BA sebesar $25 \%$, dan $50 \%$ yang mengalami pecah benih pada hari ke 3 . Sedangkan penambahan BA menjadi $75 \%$, dan $100 \%$ pada tanaman Sawi ini mengakibatkan masa pecah benih menjadi lebih cepat yaitu 2 hari dari masa tanam. Perilaku tanaman Kangkung tidak jauh berbeda dengan kedua tanaman yang lain. Pada prosentase BA $0 \%$ dan $25 \%$, benih kangkung mengalami pecah benih pada hari ke 5 semenjak di tanam, sedangkan dengan prosentase BA $50 \%$, $75 \%$, dan $100 \%$ tanaman Kangkung semakin cepat mengalami pecah benih, yaitu pada hari ke 4 .

\section{Pengujian Ketiga Seluruh Prosentase}

Pengujian semakin diperkuat dengan dilakukannya pengujian ketiga, pada pengujian kali ini tanaman Selada memiliki kecenderungan yang sedikit berbeda dengan sebelumnya. Selada 0\%BA mengalami pecah benih pada hari ke 3 , Selada dengan 25\% BA dan 50\% BA memiliki waktu yang relatif lebih cepat, yaitu 2 hari untuk dapat tumbuh. Sedangkan Selada dengan $75 \%$ BA mengalami pecah benih kembali pada hari ke tiga, sedangkan 
Selada dengan prosentase BA 100\% mengalami pecah benih pada hari ke 2 .

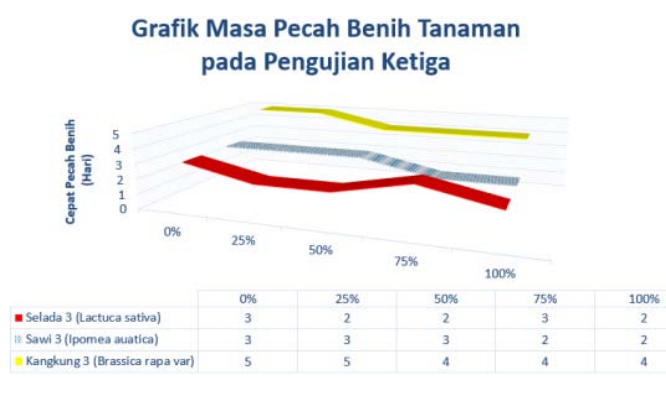

Grafik 3. Grafik Masa Pecah Benih Tanaman pada Pengujian Ketiga

\section{Analisis Kondisi Tanaman Selada (Lactuca sativa) Berdasarkan Prosentase Bottom Ash}

Hasil pendataan masa pecah benih pada tanaman selada, baik Selada 1, Selada 2, dan Selada 3 dimulai dari prosentase terkecil yaitu $0 \%$ BA sampai dengan kandungan $100 \%$ BA menunjukkan bahwa tanaman ini dapat tumbuh dengan relatif stabil dengan kecenderungan rata rata bahwa semakin banyak prosentase Bottom Ash maka tanaman Selada akan semakin cepat dalam pecah benih. Meskipun pada grafik tampak satu anomali yaitu pada tanaman selada 3 dengan prosentase BA $75 \%$ menunjukkan masa pecah benih yang lebih lambat satu hari dibandingkan prosentase yang lebih rendah, akan tetapi karena kecenderungan pada Selada 1 dan Selada 2 meunjukkan arah yang lebih stabil, maka pada Selada 1 dengan prosentase $75 \%$ di duga mengalami gangguan selama proses penanamannya sehingga menghasilkan anomali (Grafik 4).

Kemampuan bertahan tanaman Selada selama masa tanam yaitu 55 hari juga relatif seragam. Selada 1 dengan variasi prosentase Bottom Ash nya (0\%, 25\%, 50\%, 75\%, dan 100\%) rata - rata mampu bertahan dari mulai pecah benih sampai dengan hari terakhir pengamatan, yaitu selama 54 hari. Selada 2 pada prosentase $0 \%$ Bottom Ash dikarenakan mengalami lambat pecah benih 1 hari, maka pada hari ke 55, Selada $20 \%$ Bottom Ash ini berumur 53 hari. Sedangkan Selada 2 dengan prosentase $25 \%, 50 \%, 75 \%$, dan $100 \%$, pada hari ke 55 telah berumur 54 hari. Selada 3 dengan variasi prosentase BA $0 \%$ dan $25 \%$, pada hari terakhir pengamatan, selada tersebut berumur 53 hari. Sedangkan pada kenaikan prosentase BA yaitu 50\%, 75\%, dan 100\% BA, Selada 3 mempunyai umur yang relatif lebih tua yaitu 54 hari (Grafik 5). Berdasarkan hal tersebut, dapat ditarik kesimpulan bahwa semakin besar prosentase Bottom Ash maka tanaman Selada ini pada batas hari terakhir penelitian (hari ke 55) berumur lebih tua karena mengalami pecah benih lebih awal.
Grafik Pecah Benih Tanaman Selada (Lactuca sativa) Berdasarkan \% Bottom Ash

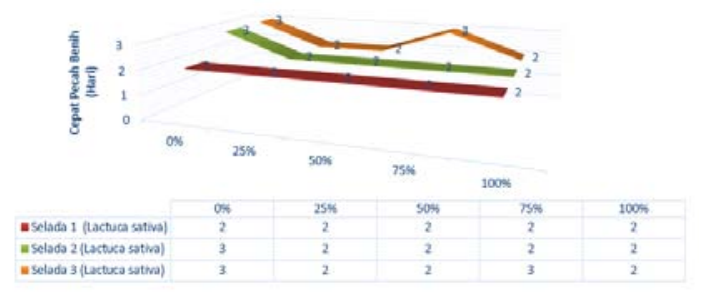

Grafik 4. Grafik Masa Pecah Benih Tanaman Selada Grafik Umur Tanaman Selada (Lactuca sativa) Berdasarkan \% Bottom Ash

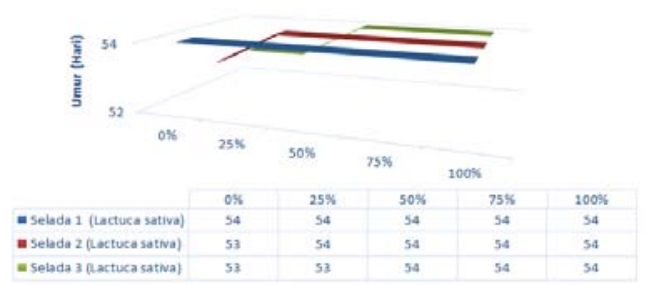

Grafik 5. Grafik Umur Tanaman Selada pada hari ke 55.

Parameter lain dalam pemanfaatan Bottom Ash sebagai media tanam ini adalah, kuat tumbuh tanaman atau umur tanaman, kondisi tanaman selama batas waktu yang di tentukan. Tanaman Selada 0\% BA, pecah benihnya dapat dikatakan baik dan relatif lebih cepat dari pada prediksi yang diberikan oleh produsen benih. Selain itu tanaman Selada 0\% BA memiliki pertumbuhan yang baik dan tidak mengalami anomali. Sedikit perbedaan secara fisik dapat dilihat pada Selada dengan prosentase BA 25\% memiliki pertumbuhan yang sangat subur melebihi Selada yang ditanam dengan media tanam $100 \%$ sekam padi bakar. Selada 25\% BA memiliki daun yang lebih lebat dan lebih tegak serta lebih kokoh (Gambar 14).

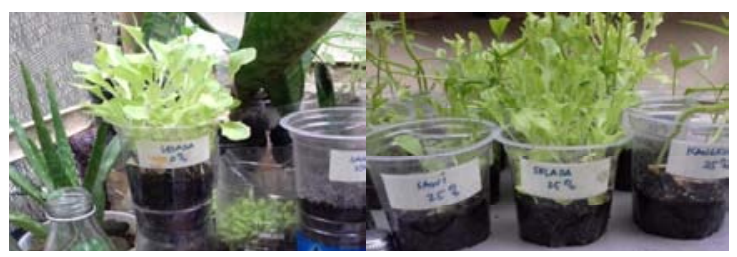

Gambar 14. Perbandingan tanaman Selada $0 \%$ BA dengan 25\% Bottom Ash

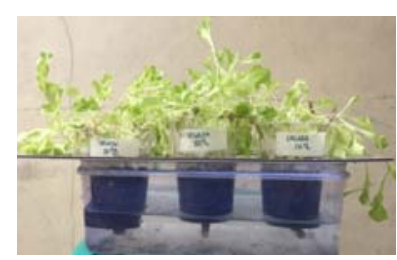

Gambar 15. Tanaman Selada dengan prosentase 50\% Bottom Ash.

Pertumbuhan tanaman Selada pada variasi $50 \%, 75 \%$, memiliki perilaku yang hampir sama, pertumbuhannya sangat subur, akan tetapi jika diperhatikan kondisi fisiknya Selada dengan prosentase $50 \%$ dan $75 \%$ cenderung berbatang 
lebih panjang (bongsor) dikarenakan melimpahnya unsur hara makro seperti Natrium yang tersedia baik melalui media tanam Bottom Ash dan juga air nutrisi (AB MIX). Akan tetapi kelebihan unsur hara Natrium ini dapat mengakibatkan batang menjadi lebih lunak sehingga mudah rebah dan terserang penyakit. Pada awalnya pada prosentase ini tanaman dapat tumbuh dengan tegak, akan tetapi dikarenakan faktor eksternal seperti hujan lebat yang terjadi terus menerus dan sangat sedikit sinar matahari yang didapatkan, maka lama kelamaan akhirnya mempengaruhi pertumbuhan tanaman Selada pada prosentase $50 \%$ dan $75 \%$ ini. Selain unsur hara, beberapa faktor eksternal yang mempengaruhi tanaman untuk dapat bertahan hidup adalah kelembaban, oksigen, cahaya, udara, dan polusi atau pencemaran.

Curah hujan yang tinggi mengakibatkan pencucian nutrisi yang ada pada media tanam, yaitu Silika pada sekam padi bakar dan unsur hara yang terdapat pada Bottom Ash. Selain itu, kadar air yang tinggi akibat hujan lebat terus menerus mengakibatkan konsentrasi pada air nutrisi sebagai pengganti unsur hara pada tanah dalam metode penanaman hidroponik juga mengalami penurunan. Akibatnya air nutrisi menjadi lebih encer sehingga kebutuhan tanaman akan unsur hara serta silika untuk mengoptimalkan penyerapan nutrisinya juga tidak diperoleh oleh tanaman, sehingga pada akhirnya tanaman akan menjadi kekuningan dan rebah (tidak tegak) meskipun tanaman tetap tumbuh.

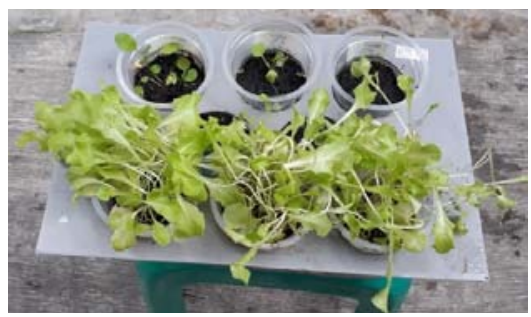

Gambar 16. Tanaman Selada dengan prosentase $75 \%$ Bottom Ash

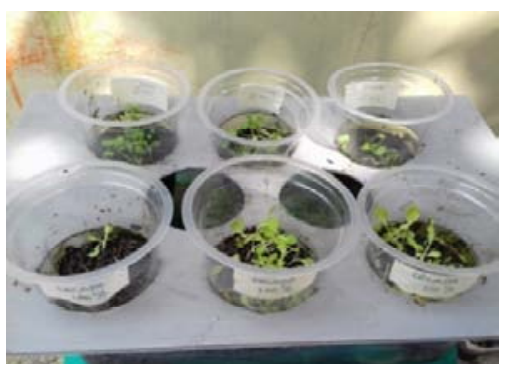

Gambar 17. Tanaman Selada dengan prosentase 100\% Bottom Ash.

Pertumbuhan selada dengan variasi prosentase $100 \%$ memiliki perilaku pertumbuhan yang relatif berbeda dengan prosentase yang lebih rendah. Pada awalnya Selada prosentase $100 \%$ BA ini memiliki waktu pecah benih yang relatif cepat yang berarti selada ini memiliki pertumbuhan yang relatif baik dan yang cepat. Akan tetapi pada saat memasuki musim penghujan, dengan curah hujan tinggi, terlihat selada mengalami perubahan fase pertumbuhan menjadi tidak begitu subur dengan warna daun yang tidak begitu hijau, bahkan cenderung kekuningan. Daun pada Selada prosentase $100 \%$ BA ini cencerung lebih sedikit dibandingkan dengan prosentase lainnya. Analisis yang dapat diberikan pada variasi BA $100 \%$ ini adalah faktor eksternal hujan lebat yang terjadi terus menerus sehingga mengakibatkan terjadinya pencucian unsur hara salah satunya adalah Nitrogen yang mengakibatkan daun tidak berwarna hijau segar bahkan cenderung menguning, pertumbuhan tanaman melambat, dan lemah. Kekurangan phospor akibat pencucian air hujan juga mengakibatkan pertumbuhan tanaman menjadi lambat dan kerdil/ kecil, serta mudah rontok. Hal ini dikarenakan phospor berguna untuk merangsang pertumbuhan. Kurangnya sinar matahari mengakibatkan tanaman kesulitan dalam mengekstrak klorofil dan menghambat metabolisme tanaman sehingga menambah efek pencucian akibat hujan.

Komposisi $100 \%$ BA sebagai media tanam dapat dikatakan kurang sesuai di terapkan sebagai media tanam tanaman Selada. Selain kondisi kekurangan nutrisi pada tanaman, kelebihan unsur hara juga dapat memberikan dampak kurang bagus terhadap tanaman. Bottom Ash memiliki kandungan salah satunya adalah Magnesium (Mg), air penutrisi (AB MIX) juga mempunyai kandungan Magnesium (Mg). Hal tersebut berarti dapat mengakibatkan tanaman yang di tanam dengan media tanam 100\% BA menjadi berpotensi mengalami kelebihan unsur hara, salah satunya adalah Magnesium. Kelebihan magnesium pada selada dapat di tandai dengan terhambatnya pertumbuhan tanaman, perakaran yang terganggu sehingga tanaman menjadi kerdil (Gambar 17)

\section{E. Analisis Kondisi Tanaman Sawi (Ipomea auatica) Berdasarkan Prosentase Bottom Ash}

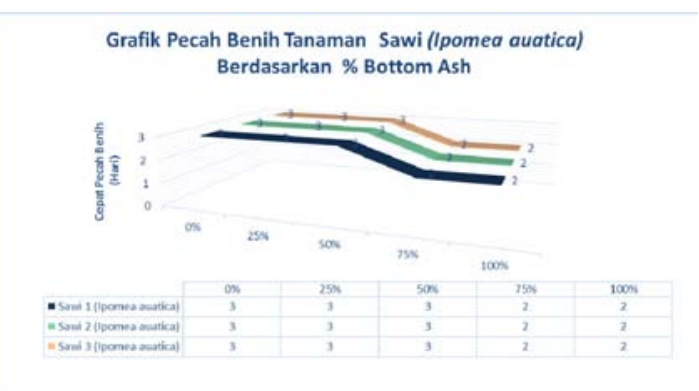

Grafik 6. Grafik pecah benih tanaman Sawi (Ipomea autica) berdasarkan prosentase Bottom Ash. 


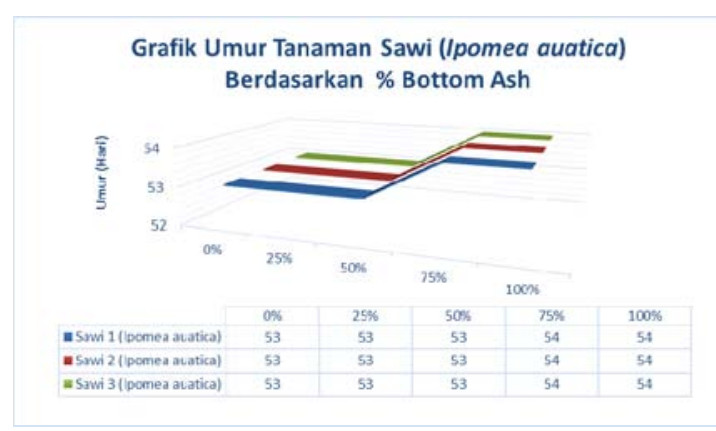

Grafik 7. Grafik umur tanaman Sawi (Ipomea Autica) berdasarkan prosentase Bottom Ash.

Tanaman Sawi mempunyai pola yang relatif sama saperti pada tanaman Selada. Pecah benih pada tanaman Sawi, baik Sawi 1, Sawi 2, dan Sawi 3 mulai dari prosentase terkecil yaitu 0\% BA sampai dengan kandungan $100 \%$ BA menunjukkan kecenderungan yang sama, yaitu semakin banyak prosentase Bottom Ash maka tanaman Selada akan semakin cepat dalam pecah benih (Grafik 6). Variasi 0\%, 25\%, dan 50\% Bottom Ash mengalami pecah benih pada hari ke tiga setelah ditanam, sedangkan pada prosentase $75 \%$ dan $100 \%$ Bottom Ash tanaman mengalami pecah benih pada hari kedua setalah ditanam. Kemampuan bertahan tanaman Sawi mulai dari variasi $0 \%$ sampai dengan $100 \%$ juga mempunyai kecenderungan yang sama yaitu, semakin besar prosentase Bottom Ash maka pada hari ke 55 tanaman Sawi tersebut memiliki umur yang lebih tua karena mengalami pecah benih lebih awal (Grafik 7). Variasi Bottom Ash 0\%, 25\%, dan $50 \%$ pada hari ke 55 telah berumur 53 hari, sedangkan pada prosentase $75 \%$ dan $100 \%$ tanaman Sawi telah berumur 54 hari. Tanaman Sawi dapat pecah benih kemudian tumbuh dengan baik pada prosentase 0\% Bottom ash, yang berarti media tnaman yang digunakan adalah murni sekam padi bakar. Pertumbuhan Sawi \% BA ini murni unsur hara yang berasal dari air nutrisi yang penyerapannya di optimalkan oleh unsur silika yang terdapat pada sekam padi bakar.

Pertumbuhan yang sangat baik juga terjadi pada tanaman Sawi dengan prosentase 25\% kandungan Bottom Asnya. Tanaman Sawi tumbuh dengan kondisi kuat atau tegak dan lebih subur pada bagian daunnya. Hal ini dipengaruhi oleh tambahan unsur hara yang didapatkan dari Bottom Ash, seperti calsium yang merupakan unsur dominan untuk titik tumbuh tanaman, terlihat dari pertumbuhan bijih Sawi relatif cepat mengalami pecah benih. Unsur magnesium (Mg) juga lebih banyak hadir pada prosentase ini akibat penambahan Bottom Ash. Magnesium merupakan unsur hara esensial yang berfungsi sebagai aktivator dan transportasi enzim,empercepat produksi sel, fotosintesis dan transfer energi keseluruh bagian tanaman. Selain itu, Kedua unsur makro tersebut dapat dimanfaatkan secara maksimal oleh tanaman karena hadirnya silika yang melimpah, yaitu silika yang berasal dari Bottom Ash dan sekam padi bakar

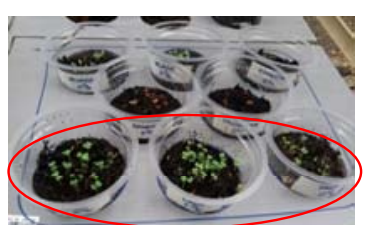

Gambar 18. Tanaman Sawi dengan prosentase $0 \%$ Bottom Ash.

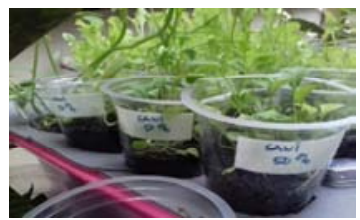

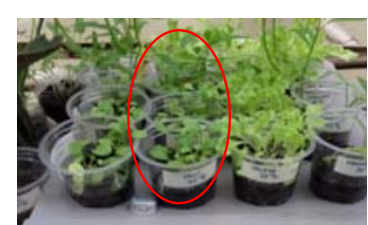

Gambar 19. Tanaman Sawi dengan prosentase $25 \%$ Bottom Ash.
Gambar 20. Tanaman Sawi dengan prosentase $50 \%$ Bottom Ash.

Sawi dengan prosentase 50\% Bottom Ash terlihat hampir sama pertumbuhannya seperti pada prosentase sebelumnya. Biji sawi mengalami pecah benih pada hari ke tiga setelah ditanam. Sehingga pada hari ke 55, umur tanaman ini adalah 53 hari. Pada prosentase ini media kaya akan $\mathrm{Ca}$ dan Magnesium dan Natrium yang berasal dari air nutrisi serta penambahan unsur makro yang sama dari media tanam Bottom Ash. Perbedaan yang tampak pada prosentase ini adalah, pengamatan dilakukan beberapa hari setelah hujan lebat, akibatnya beberapa tanaman Sawi mengalami roboh atau tidak tegak meskipun tidak semuanya dan pertumbuhan daun berubah menjadi warna hijau muda. Hal tersebut dapat menjadi gejala defisiensi unsur hara seperti Nitrogen pada tanaman yang di akibatkan oleh pengenceran kosentrasi pada air nutrisi serta pencucian unsur hara pada media tanam.

Tanaman Sawi dengan prosentase $75 \%$ dan $100 \%$ kandungan Bottom Ash mengalami pertumbuhan yang relatif lebih cepat dari prosentase yang lebih rendah. Prosentase $75 \%$ dan $100 \%$ BA mengalami pecah benih pada hari ke 2 setalah benih di tanam (Gambar 21). Pertumbuhan tanaman ini juga relatif cepat dan subur. Tersedianya unsur hara makro dan mikro yang melimpah pada media tanam Bottom Ash serta di tambah dengan air nutrisi ABMIX menjadikan alasan mengapa tanaman Sawi dengan prosentase $75 \%$ dan 100\& Bottom Ash ini dapat tumbuh dengan subur.

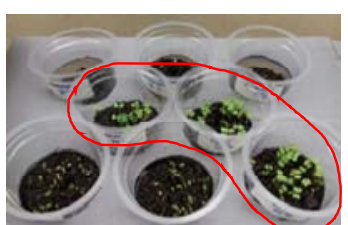

Gambar 21.Tanaman Sawi dengan prosentase $75 \%$ Bottom Ash.

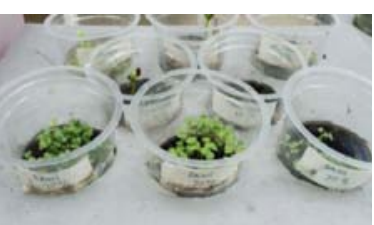

Gambar 22. Tanaman Sawi dengan prosentase $75 \%$ Bottom Ash setelah terjadi hujan lebat terus menerus. 


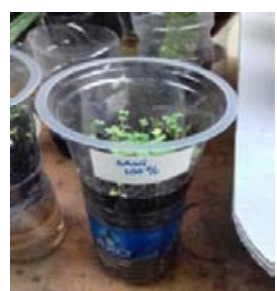

Gambar 23.Tanaman Sawi dengan prosentase $100 \%$ Bottom Ash.

Kendala yang di hadapi masih sama, yaitu hujan lebat yang terjadi terus menerus mengakibatkan pencucian unsur hara yang terkandung dalam media tanam Bottom Ash seperti Calsium, Magnesium dan Natrium serta pengenceran nutrisi tanaman yang terkandung dalam air nutrisi ABMIX. Setelah pecah benih dengan cepat, daun yang tumbuh berubah warna dari hijau menjadi hijau muda bahkan relatif kekuningan pada beberapa sampel tanaman Prosentase $70 \%$ dan $100 \%$. Perubahan warna daun dari hijau menjadi hijau muda kemudian kekuningan, dapat mengindikasikan adanya defisiensi beberapa unsur hara, baik makro maupun mikro.

\section{F. Analisis Kondisi Tanaman Kangkung (Brassica rapa var) Berdasarkan Prosentase Bottom Ash \\ Tanaman Kangkung memiliki pola masa} pecah benih yang hampir serupa dengan tanaman yang lain. Hanya saja pada tanaman ini, prosentase $50 \%$ sudah mengalami percepatan pecah benih. Variasi $0 \%$ dan 25\% Bottom Ash mengalami pecah benih pada hari ke 5 setelah benih di tanam. Sedangkan mulai variasi $50 \%, 75 \%$, dan $100 \%$ Bottom Ash mengalami pecah benih pada hari ke 4 . (Grafik 8), sehingga pada hari ke 55 grafik umur tanaman inipun cenderung semakin tua seiring dengan penambahan prosentase BA (Grafik 9).

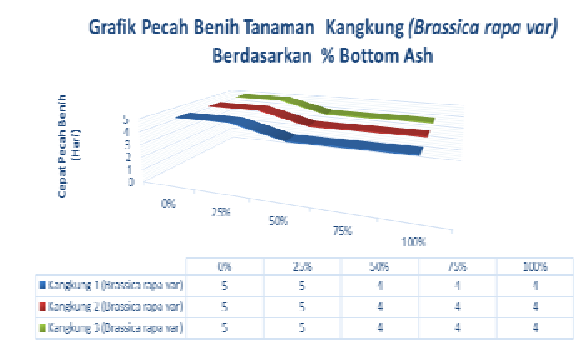

Grafik 8. Grafik Pecah Benih pada tanaman Kangkung (Brassica rapa var)

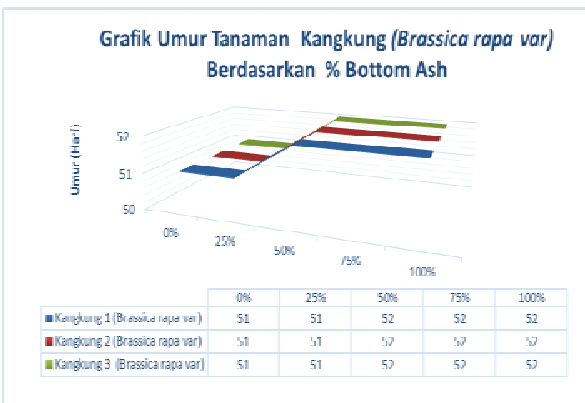

Grafik 9.Grafik umur pada tanaman Kangkung (Brassica rapa var)

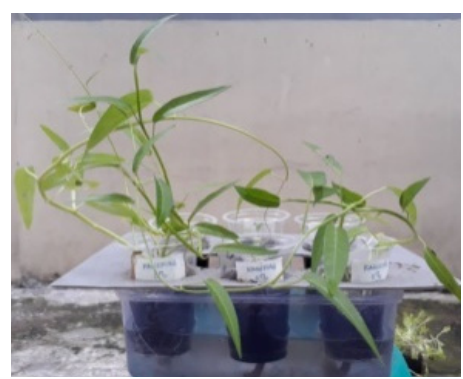

Gambar 24. Tanaman Kangkung (Brassica rapa var) variasi $0 \%$ Bottom Ash.

Tanaman Kangkung variasi 0\% Bottom Ash mengalami pecah benih pada hari ke 5 setelah di tanam. Hal tersebut menunjukkan bahwa dalam kondisi normal benih yang dipergunakan dapat tumbuh dengan baik. Daun berwarna hijau dan memiliki ukuran panjang batang yang normal atau sedang. Kangkung 0\% BA tumbuh dengan model tidak lurus vertikal akan tetapi bergelombang. Kangkung dengan variasi media tanam 25\% BA mengalami pecah benih pada hari ke 5 , tanaman tumbuh dengan baik, secara fisik tidak dijumpai anomali jika di bandingkan dengan Kangkung prosentase 0\%BA. Dengan demikian pada prosentase $25 \%$ BA dapat dikatakan bahwa tanaman mendapatkan cukup unsur hara atau penambahan $25 \%$ BA masih sesuai dengan kebutuhan.

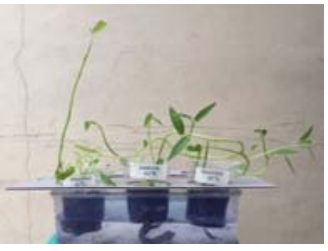

Gambar 25. Tanaman Kangkung (Brassica rapa var) variasi $25 \%$ Bottom Ash.

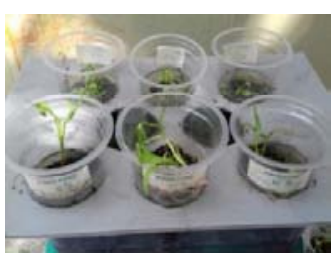

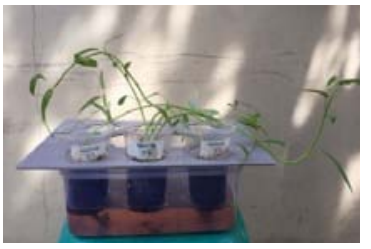

Gambar 26. Tanaman Kangkung (Brassica rapa var) variasi $50 \%$ Bottom Ash.
Kangkung variasi $50 \%, 75 \%$ dan $100 \%$ BA memiliki masa pecah benih yang sama, yaitu 4 hari setalah di tanam. Sehingga pada hari ke 55, umur ke tiga prosentase kangkung ini adalah sama yaitu 52 hari. Secara fisik, kangkung prosentase 50\% (Gambar 26) memiliki batang yang lebih panjang jika dibandingkan dengan prosentase yang lebih rendah (pengamatan dilakukan pada umur yang sama), hal tersebut menunjukkan bahwa penambahan unsur hara oleh Bottom Ash pada prosentase ini telah memberikan dampak pada pertumbuhan tanaman Kangkung. Pengambilan gambar dan pengamatan dilakukan pada Kangkung variasi $75 \%$ BA saat berumur 1 minggu, biji kangkung memiliki waktu pecah benih yang relatif cepat, pertumbuhan batang dan daun serta akar 
terjadi dengan sangat baik. Tumbuhnya tanaman kangkung variasi $75 \%$ BA ini terkendala oleh turunnya hujan lebat dan terjadi hampir setiap hari.

Pada tanaman Kangkung variasi 100\% Bottom Ash, mangalami pecah benih dalam waktu yang relatif cepat dan memiliki batang yang lebih panjang dari prosentase yang lebih kecil. Akan tetapi pada prosentase ini jumlah daun relatif sedikit. Melimpahnya unsur hara yang pada prosentase ini dapat menimbulkan ketidakseimbangan antara unsur hara makro (Nitrogen, Phospor, Kalium, Calsium, Magnesium, Sulfur) dengan unsur hara mikro (Besi, Mangan, Buron, Klor, Molibdenum, Tembaga, Natrium, Seng, Cobalt, Nikel). Pada unsur mikro jika berlebihan akan berdampak menjadi racun yang berpengaruh terhadap pertumbuhan tanaman. Keseimbangan antara unsur makro dan mikro nampaknya adalah hal yang sangat penting Pada tanaman kangkung (Djukri, Enviro 2005). Analisa lain yang dapat diberikan adalah karena adanya kendala hujan lebat yang terjadi terus menerus, media tanam dan air nutrisi (ABMIX) menjadi menurun konsentrasinya seperti unsur Nitrogen menjadi tidak terpenuhi, akibatnya adalah daun menjadi kerdil dan lama kelamaan akan berwarna kekuningan (Salibury dan Ross, 1992 dalam Djukri 2005).

\section{G. Kendala Yang Dihadapi}

Kendala - kendala yang dihadapi selama penelitian berlangsung antara lain sebagai berikut:

1. Pelaksanaan pengujian bersamaan dengan musim penghujan, dengan curah hujan yang tinggi dan intensitas yang sering mengakibatkan tanaman menjadi roboh karena terkena air hujan yang deras.

2. Air hujan dapat mengenencerkan konsentrasi air nutrisi tanaman, sehingga mengakibatkan kebutuhan nutrisi tanaman melalui air nutrisi tersebut menjadi tidak terpenuhi.

3. Air hujan dapat mengakibatkan pencucian kandungan unsur hara yang terdapat pada media tanam baik Bottom Ash maupun Sekam Padi Bakar. Hal tersebut dapat membuat tanaman semakin tidak terpenuhi kebutuhan nutrisinya (unsur hara) sehingga mengakibatkan tanaman tumbuh dengan tidak semestinya.

4. Faktor eksternal lain yang mengganggu pertumbuhan tanaman adalah kurangnya sinar matahari yang sangat mempengaruhi proses fotosintesis dari tanaman.

5. Gangguan dari binatang liar seperti tikus, kucing sangat mempengaruhi kelangsungan hidup tanaman.

\section{Rencana Lanjutan Penelitian}

Berdasarkan pengujian yang telah dilakukan, serta kendala - kendala yang dihadapi selama penelitian berlangsung, maka diperlukan penelitian lebih lanjut tentang beberapa hal seperti:

a. Kandungan unsur hara yang terdapat pada air nutrisi (ABMIX).

b. Kandungan unsur hara yang terdapat pada Bottom Ash limbah PLTU Suralaya.

c. Kandungan unsur hara yang terjadi melalui penambahan unsur hara yang terdapat pada
Bottom Ash apakah sesuai dengan kebutuhan jenis tanaman atau tidak.

d. Kandungan logam berat pada Bottom Ash limbah PLTU Suralaya.

e. Kandungan kadar logam berat atau kadar toksin yang terdapat dari tanaman yang dihasilkan dari penanaman dengan menggunakan limbah Bottom Ash sebagai media tanamnya.

Beberapa hal diatas sangat diperlukan guna mengetahui efisiensi serta kelayakan pemanfaatan Bottom Ash sebagai media tanam dilihat dari aspek resiko dan bahayanya.

\section{KESIMPULAN}

Berdasarkan pengujian yang dilakukan, dapat ditarik beberapa kesimpulan antara lain sebagai berikut:

a. Bottom Ash dapat di gunakan sebagai media tanam Hydroponik pada tanaman sayur Selada atau Lactuca sativa, Sawi atau Ipomea Autica, dan Kangkung atau Brassica rapa var.

b. Bottom Ash dapat dipergunakan hampir di semua variasi prosentase, semakin banyak prosentase BA maka benih akan semakin cepat pecah dan tanaman tumbuh dengan lebih cepat. Karena ketersediaan unsur $\mathrm{Ca}$, $\mathrm{Mg}, \mathrm{Na}, \mathrm{K}, \mathrm{N}, \mathrm{P}, \mathrm{S}$ dan Fe dalam jumlah yang banyak.

c. Prosentase BA paling sesuai diterapkan sebagai media tanam untuk tanaman Selada adalah $25 \%$.

d. Prosentase Bottom Ash yang paling sesuai diterapkan sebagai media tanam pada tanaman Sawi adalah 25\% dan 50\%.

e. Prosentase Bottom Ash yang paling sesuai digunakan sebagai media tanam untuk tanaman Kangkung adalah 25\%, 50, 75\%.

f. Meskipun Bottom Ash dapat dipergunakan dalam seluruh prosentase, akan tetapi pada prosentase $100 \%$ terdapat beberapa sampel yang tidak maksimal pertumbuhannya yaitu pada Tanaman Sawi dan Selada. Pada Sawi, tanaman tumbuh dengan daun berwarna hijau muda bahkan kekuningan. Sedangkan pada Selada, tanaman tumbuh dengan ukuran daun dan batang yang lebih kecil (kerdil). Dikarenakan hal tersebut dapat terjadi karena dua kemungkinan, yaitu defisiensi atau bahkan kelebihan unsur hara, maka perlu di lakukan pengujian laboratorium lebih lanjut tentang kandungan unsur hara dan kebutuhan tanamannya. Sehingga pada variasi $100 \%$ Bottom Ash sebagai media tanam tidak dapat direkomendasikan terlebih dahulu.

g. Unsur yang dipergunakan untuk mempercepat pertumbuhan tanaman pada media tanam ini adalah unsur silika yang terdapat pada sekam padi bakar dan juga Bottom Ash. Dimana unsur silika ini berperan dalam optimalisasi penyerapan unsur hara pada tanaman sehingga pertumbuhan tanaman menjadi lebih cepat.

h. Terdapat potensi kelebihan penyerapan unsur hara dikarenakan tersedianya unsur hara 
secara ganda yaitu pada air penutrisi (ABMIX) dan Bottom Ash sebagai media tanamnya seperti Kalsium, Magnesium, Natrium, dan beberapa usur mikro seperti kandungan logam Besi (Fe), Sulfur (S), dan Almunium (Al), maka Potensi kelebihan unsur hara yang terjadi harus dibuktikan melalui pengujian laboratorium agar lebih akurat.

i. Kelebihan unsur hara dapat menimbulkan anomali pertumbuhan secara fisik seperti batang lebih panjang, jumlah daun sedikit, akar menjadi lebih panjang, kekerdilan tanaman, bahkan tanaman menjadi mati.

j. Tanaman hasil penelitian dan pengujian ini tidak direkomendasikan untuk dikonsumsi karena belum dilakukan pengujian kadar toksin yang terdapat didalamnya.

k. Dengan penelitian lanjutan (Uji laboratorium) diharapkan pemanfaatan limbah abu pembakaran barubara (Bottom Ash) akan menjadi lebih nyata dan akurat guna mendukung pengembangan pemanfaatan limbah secara berkelanjutan.

\section{DAFTAR PUSTAKA}

\section{Buku}

Anonim, 2008, Uraian Pemanfaatan Limbah Fly Ash dan Bottom Ash PT Daliatex Kusuma, Bandung.

Eviati, dkk., 2009, Petunjuk Teknis 2: Analisis Kimia Tanah, Tanaman, Air dan Pupuk, Balai Penelitian Tanah Departemen Pertanian, Bogor.

Kementrian Lingkungan Hidup, 2006, Himpunan Peraturan di Bidang Pengelolaan Lingkungan Hidup dan Penegakan Hukum Lingkungan.

PLN (Persero), PT, 2016, Workshop Pemanfaatan FA BA, Yogyakarta.

PLN (Persero), PT, 2015, Dokumen ANDAL PLTU Indramayu, Unit Induk Pembangunan Jaringan Jawa Bali (UIPJJB), Indramayu.

\section{Disertasi}

Kurniawan, dkk., 2010, Penelitian Pemanfaatan Abu Batubara PLTU Untuk Penimbunan Pada Pra Reklamasi Tambang Batubara, Puslitbang Teknologi Mineral dan Batubara Badan Litbang Energi dan Sumber Daya Mineral, Bandung.

\section{Jurnal}

Balai Penelitian Tanah, Warta Penelitian dan Pengembangan Pertanian, Volume 32 Nomor 3, 2010

Djukri 2005. Pertumbuhan dan Produksi Kangkung pada Berbagai Dosis Hara Makro dan Mikro. Jurnal Enviro 5 (1): 34 - 37 PPLH - PPM, UNS Surakarta.

Resh, 1998. Dalam Djukri 2005. Pertumbuhan dan Produksi Kangkung pada Berbagai Dosis Hara Makro dan Mikro. Jurnal Enviro 5 (1): 34 - 37 PPLH - PPM, UNS Surakarta.
Ramana, Adimas Bayu, 2016, Pemanfaatan Fly Ash Pada Pembuatan Paving Geopolimer Dengan Mutu K-500 Untuk Skala Industri, Fakultas Teknik Sipil dan Perencanaan, Institut Teknologi Sepuluh November, Surabaya.

Sumaryanto, 2010, Pengelolaan Limbah Fly Ash dan Bottom Ash Pada PLTU Batubara, Pertemuan Pengelolaan Lingkungan Sektor Energi dan Sumber Daya Mineral, Jakarta.

Susila, A.D., 2013, Modul Kuliah Dasar-Dasar Hortikultura: Sistem Hidroponik, Institut Pertanian Bogor, Bogor.

Salibury dan Ross, 1992. Dalam Djukri 2005. Pertumbuhan dan Produksi Kangkung pada Berbagai Dosis Hara Makro dan Mikro. Jurnal Enviro 5 (1): 34 - 37 PPLH - PPM, UNS Surakarta.

Mengenal Silika sebagai Unsur Hara, Volume 32 Nomor 3, 2010, Jurnal Warta Penelitian dan Pengembangan Pertanian, Balai Penelitian Tanah

\section{Publikasi Elektronik}

Anonim, Limbah B3: Pengertian, Contoh, Sifat, dan Karakteristiknya, http://www.ebiologi.com/2017/01/limbah-b3pengertian-contoh-sifat-dan.html, Diakses pada 30 Oktober 2017 pukul 09:00 WIB.

Azzamy, August 28, 2015 Manfaat Arang Sekam Sebagai Media Tanam Hidroponik dan Konvensional

Pemanfaatan Sekam Padi Bakar https://warasfarm.wordpress.com/2013/07/3 1/pemanfaatan-sekam-padi http://www.belajarbarenghidroponik.com/201 6/01/kandungan-nutrisi-hidroponik-abmix.html\#.WoE97CWLnIU 